\title{
Case Report: PTHrP Related Hypercalcemia in Diffuse Large B-cell Lymphoma
}

\author{
Ankita Mehta, MD \\ Thomas Jefferson University Hospital, ankita.mehta@jefferson.edu \\ Evan Caruso, MD \\ Thomas Jefferson University, evan.caruso@jefferson.edu
}

Follow this and additional works at: https://jdc.jefferson.edu/tmf

Part of the Internal Medicine Commons, and the Oncology Commons

Let us know how access to this document benefits you

\author{
Recommended Citation \\ Mehta, MD, Ankita and Caruso, MD, Evan (2016) "Case Report: PTHrP Related Hypercalcemia in Diffuse \\ Large B-cell Lymphoma," The Medicine Forum: Vol. 17, Article 10. \\ DOI: https://doi.org/10.29046/TMF.017.1.011 \\ Available at: https://jdc.jefferson.edu/tmf/vol17/iss1/10
}

This Article is brought to you for free and open access by the Jefferson Digital Commons. The Jefferson Digital Commons is a service of Thomas Jefferson University's Center for Teaching and Learning (CTL). The Commons is a showcase for Jefferson books and journals, peer-reviewed scholarly publications, unique historical collections from the University archives, and teaching tools. The Jefferson Digital Commons allows researchers and interested readers anywhere in the world to learn about and keep up to date with Jefferson scholarship. This article has been accepted for inclusion in The Medicine Forum by an authorized administrator of the Jefferson Digital Commons. For more information, please contact: JeffersonDigitalCommons@jefferson.edu. 


\title{
Case Report: PTHrP Related Hypercalcemia in Diffuse Large B-cell Lymphoma
}

\author{
Ankita Mehta, MD, and Evan Caruso, MD
}

\section{INTRODUCTION}

Hypercalcemia is commonly associated with solid tumor malignancies, but less often with hematologic malignancies. When present in hematologic malignancies, hypercalcemia is often secondary to overproduction of Vitamin D from the tumor cells. Very few cases with parathyroid hormone related peptide (PTHrP) induced hypercalcemia in B-cell lymphomas have been reported. Here we present a 44 year old male with a history of chronic lymphoctic leukemia who presented with hypercalcemia and an elevated PTHrP, found to have a transformation to Diffuse Large B-cell Lymphoma (DLBCL).

\section{CASE PRESENTATION}

A 44 year old male with chronic lymphocytic leukemia (CLL) status post four cycles of rituximab, cyclophosphamide, vincristine and prednisone and currently undergoing treatment with ibrutinib presented with two weeks of decreased appetite, fatigue, weakness, altered mental status. Physical exam was only significant for mild cervical lymphadenopathy. Labs revealed hypercalcemia at $18.1 \mathrm{mg} / \mathrm{dL}$, compared to $12 \mathrm{mg} / \mathrm{dL}$ one month prior to admission. Work up of hypercalcemia revealed normal intact PTH and Vitamin D levels, and elevated PTHrP at 57 pmol/L. Upon further investigation, including a bone marrow biopsy, it was determined that the CLL had transformed to a more aggressive subtype, diffuse large B-cell Lymphoma. He did not complain of any abdominal pain, but did complain of diffuse bone pain. CT of the chest, abdomen, and pelvis showed adenopathy throughout with some mild splenomegaly. The patient's hypercalcemia was treated with fluids, calcitriol, and pamidronate with improvement in symptoms and normalization of calcium levels. His DLBCL was treated with a cycle of cyclophosphamide, doxorubicin, vincristine, and prednisone (CHOP). However, his neutrophil count did not recover as expected and his calcium began to increase again two weeks after initial treatment. A repeat bone marrow biopsy was consistent with refractory B-cell lymphoma. His hypercalcemia was again treated with fluids and re-dosing of pamidronate, which stabilized his calcium between 11 and $12 \mathrm{mg} / \mathrm{dL}$, but did not normalize it. He began experiencing fatigue and bone pain again. He was started on dexamethasone 6 mg every 6 hours which returned his calcium to normal range and relieved his symptoms. His calcium has remained stable since, and he is to undergo therapy with bendamustine, ofatumumab, carboplatin, and etoposide.

\section{DISCUSSION}

Though hypercalcemia is commonly seen in adult T cell lymphomas/leukemia and solid tumors via excess production of PTHrP, less than $10 \%$ of patients with non Hodgkins B-cell lymphomas develop hypercalcemia. ${ }^{2}$ The hypercalcemia seen in B cell lymphomas is usually due to non PTHrP related mechanisms. There are various explanations of the pathophysiology for hypercalcemia in hematologic malignancies. Most of the case studies that have reported B-cell lymphomas with hypercalcemia secondary to PTHrP hypersecretion are high grade lymphomas. Our patient's case supports these findings, as he too had a Richter's transformation on bone marrow biopsy. ${ }^{1}$ Correlation between the concentration of the protein and the degree of hypercalcemia suggests a causal relationship. Numerous case reports have shown that hypercalcemia in B cell lymphoma is a poor prognostic factor. In Majmudar's article, of the eight patients he reported, median survival time from developing hypercalcemia was nine months. ${ }^{3}$

\section{KEY POINTS}

The mechanisms of hypercalcemia in hematologic malignancies are multifactorial and yet to be fully understood. However, it is important to evaluate the cause and promptly treat the hypercalcemia. It is imperative to determine calcium levels given that it is a prognostic indicator and of clinical significance. PTHrP mediated hypercalcemia is rare in B cell lymphomas, but has been reported in high grade and transformed disease and should be considered in the evaluation of hypercalcemia in this subset of patients.

\section{REFERENCES}

1. Beaudreuil J. "Hypercalcemia May Indicate Richter's Syndrome: Report of Four Cases and Review." Cancer. 1997; 79(6):1211-215.

2. Ghazi AA, Attarian H, Attarian S, Abasahl A, Daryani E, Farasat E, et al. "Hypercalcemia and Huge Splenomegaly Presenting in an Elderly Patient with B-cell Non-Hodgkin's Lymphoma: A Case Report." J Med Case Rep Journal of Medical Case Reports. 2010; 4: 330

3. Majumdar G. "Incidence and Prognostic Significance of Hypercalcaemia in B-cell Non-Hodgkin's Lymphoma." Journal of Clinical Pathology . 2002; 55(8): 637-638

4. Strewler GJ. "The Parathyroid Hormone-related Protein." Endocrinology and Metabolism Clinics of North America. 2000; 29(3): 629-45.

5. Amazyane T. "Humoral Hypercalcemia Revealing a Malignant Non Hodgkin Lymphoma." Annales D'Endocrinologie. 2008; 69(1): 58-62.

6. Daroszewska A, Bucknall RC, Chu, P and Fraser WD. "Severe Hypercalcaemia in B-cell Lymphoma: Combined Effects of PTH-rP, IL-6 and TNF." Postgraduate Medical Journal. 1999; 75(889):672-74.

7. Firkin F. "Parathyroid Hormone-related Protein in Hypercalcaemia Associated with Haematological Malignancy." British Journal of Haematology. 1996; 94(3): 486-92 